JECIES: Journal of Early Childhood Islamic Education Study

Vol. 02, Nomor 01, Maret 2021

DOI: http://dx.doi.org/10.33853/jecies.v2i1.

http://e-journal.stit-islamic-village.ac.id/index.php/JECIES

\title{
PEMAHAMAN GURU TAMAN KANAK-KANAK TENTANG PENGETAHUAN LAYANAN BIMBINGAN KONSELING DAN PELAKSANAAN DI KECAMATAN SOMBA OPU KABUPATEN GOWA
}

\author{
Sri Sofiani \\ Universitas Negeri Makasar \\ Email: srisofiani18@gmail.com
}

Syamsul Alam Ramli

Universitas Muhammadiyah Palopo

Email: syamsulalamramli@gmail.com

Eka Poppi Hutami

Institut Agama Islam Negeri Palopo

Email: ekapoppihutami@gmail.com

\author{
Received :18 April, 2021. Accepted: 29 April, 2021. \\ Published: 31 April, 2021
}

\begin{abstract}
Understanding kindergarten teachers about the knowledge of counseling and implementation guidance services in Somba Opu Subdistrict, Gowa Regency. Problem formulation and this research are how teachers understand guidance and counseling services in schools? and what guidance and counseling services do teachers do in learning?. This research provides an overview of teachers' understanding of guidance and counseling services implemented by teachers in learning in kindergarten. Data collection techniques through interview methods, and questionnaire distribution, as well as documentation. Data analysis in this study was conducted by Data collection, Data reduction, Display data, Data verification. The technique of examination and validity of data is carried out with The Extension of Participation, Perseverance of Questionnaires and Interviews, and Triangulation. The results showed that 20 kindergarten teachers about the understanding of knowledge guidance and counseling services are still lacking and 10 kindergarten teachers have a sufficient understanding of the knowledge of Guidance and Counseling Services. Furthermore, counseling guidance services implemented by teachers in learning in kindergarten are group guidance services, learning guidance, guidance while playing.
\end{abstract}

Keywords: Guidance and Counseling Services; Kindergarten 


\begin{abstract}
ABSTRAK
Pemahaman Guru Taman Kanak-Kanak Tentang Pengetabuan Layanan Bimbingan Konseling dan Pelaksanaan Di Kecamatan Somba Opu Kabupaten Gowa. Rumusan Masalah dam penelitian ini adalah Bagaimna pemaham guru tentang layanan bimbingan dan konseling di Sekolab? dan Layanan bimbingan dan konseling apa saja yang dilakukan guru dalam pembelajaran ?. penelitian ini memberikan gambaran pemahaman guru tentang layanan bimbingan dan konseling yang dilaksanakan guru dalam pemebelajaran di Tk. Pendekatan yang digunakan dalam penelitian ini adalab pendekatan kualitatif dan jenis penelitian adalah dengan deskriptif dan jenis pendekatan kualitatif deskriptif. Teknik pengumpulan data melalui metode wawancara, dan sebaran angket, serta dokumentasi. Analisis data dalam penelitian ini dilakukan dengan Pengumpulan data, Reduksi data, Display data, Verifikasi data. Teknik pemeriksaan dan keabsaban data dilakukan dengan Perpanjangan keikutsertaan, Ketekunan Sebaran Angket dan Wawancara, dan Triangulasi. Hasil penelitian menunjukkan bahwa 20 orang Guru Taman Kanak-kanak tentang pemahaman pengetahuan layanan Bimbingan dan Konseling masih kurang dan 10 orang Guru Taman Kanak-kanak memiliki pemahaman tentang pengetabuan layanan Bimbingan dan Konseling dengan cukup. Selanjutnya layanan bimbingan konseling yang dilaksanakan guru dalam pembelajaran di Taman Kanakkanak yaitu layanan bimbingan kelompok, bimbingan pembelajaran, bimbingan sambil bermain.
\end{abstract}

Kata Kunci: Layanan Bimbingan dan Konseling; Taman Kanak-kanak

\title{
PENDAHULUAN
}

Asumsi dasar yang melandasi bahwa Pendidikan Anak Usia Dini memerlukan bimbingan dan konseling adalah kesetaraan PAUD sekarang ini dengan pendidikan dasar menengah. Jika dilingkungan pendidikan dasar dan menengah bimbingan dan konseling sangat dibutuhkan, otomatis PAUD juga membutuhkannya. Bimbingan dan konseling selama ini cenderung hanya dikenal dilingkungan dasar dan menengah, sebagai wadah untuk mengatasi siswa-siswi yang bermasalah. Padahal sejatinya, bimbingan dan konseling harus dimulai dari jenjang PAUD seperti TPA, KB, TK atau lembaga PAUD sejenisnya.

Menurut Ahmad Susanto (2015) bahwa layanan BK di TK dapat dilakukan terpadu/terintegrasi dengan pembelajaran, adapun pelaksanaannya adalah dengan a. pendekatan intruksional, b. pendekatan dukungan sistem yaitu menciptakan suasana lingkungan TK, yang menunjang perkembangan anak, c. pendekatan pengembangan pribadi yaitu dengan cara menempatkan anak dalam kelompok berdasarkan minat dan kemampuan, d. membantu memecahkan masalah anak. 
Pemahaman Guru Taman Kanak-Kanak Tentang Pengetahuan Layanan Bimbingan

Konseling dan Pelaksanaan di Kecamatan Somba Opu Kabupaten Gowa

Layanan Bimbingan dan Konseling diberbagai lembaga pendidikan termasuk didalam PAUD merupakan program bimbingan yang bermanfaat secara positif, tidak sekedar reaktif dan korektif. Terlebih lagi, jika program bimbingan ini bersifat continue, berkelanjutan dan terus-menerus mulai dari PAUD hingga perguruan, bahkan sampai di masyarakat. Tentu, hasilnya akan jauh lebih baik dari bimbingan yang sifatnya eksiden semata.

Pada umumnya bimbingan dan konseling di dalam kelembagaan PAUD seringkali guru kelas mengalami kesulitan dalam menghadapi problematika anak didiknya. Kondisi ini sangat memprihatinkan guru PAUD dikarenakan rendahnya pengetahuan dan pengalaman bimbingan dan konseling. Menghadapi problematika ini, keberadaan bimbingan dan konseling sangat dibutuhkan dilingkungan lembaga PAUD, terutama pihak lembaga yang terkait. Pasalnya, guru sering sekali belum siap menghadapi masalah anak didiknya, dikarenakan masih banyak guru kelas tidak memiliki pengetahuan dan pengalaman dalam bimbingan dan konseling terhadap anaknya.

Hurlock (Rosmala Dewi; 2005) mengemukakan Anak TK usia 4-6 tahun disebut masa emas dimana perkembangan anak mengalami lompatan kemajuan, dari bayi lemah yang menggantung seluruh hidupnya kepada orang tua menjelma menjadi si cilik pintar bicara, pandai melompat, berlari, pandai bernyanyi, luwes menggunakan jari jemari.

Anak usia dini disamping peka terhadap perkembangan namun mudah/ peka pula untuk bermasalah, anak yang bermasalah, anak yang bermasalah akan terganggu perkembangannya untuk itu guru kelas harus mengenal gejala anak yang bermasalah supaya mudah diberi layanan bimbingan dan konseling, adapun tujuan bimbingan dan konseling menurut Erwin R. Cerler (Ahmad Susanto; 2015) adalah a. Mengembangkan perilaku yang menunjang kegiatan belajar, b. Membantu meningkatkan kesadaran diri perkembangan perasaan, c. Membiasakan anak menggunakan alat indranya dengan maksimal, d. Membimbing fantasi dan daya cipta anak, e. Membiasakan anak hidup sehat.

Menghadapi masalah ini, keberadaan bimbingan dan konseling sangat dibutuhkan demi masa pertumbuhan dan perkembangannya. Menurut (Suyadi, 2009 : 165) guru PAUD bertanggung jawab besar dalam memahami anak didiknya serta membantu perkembangan fisik-motorik, sosio-emosional, kognitif dan mental spiritual. Tanggung jawab inilah yang mendorong keharusan akan adanya bimbingan konseling di lembaga PAUD, terutama TK. Pasalnya anak didik seringkali dimasa pertumbuhan dan perkembangannya belum siap menempuh pendidikan. Karena itu guru PAUD sekaligus konselor bertugas membekali anak didiknya dengan menjaga stabilitas keseimbangan tumbuh kembang anak, baik aspek perkembangan fisik-motorik, bahasa, sosioemosional, kognitif maupun moral agama dan seni. 


\section{METODE}

Penelitian ini menggunakan pendekatan kualitatif yaitu dilakukan untuk menjelaskan rangkaian peristiwa yang terjadi selama kegiatan penelitian sehingga mendapatkan gambaran, informasi dan penjelasan yang lengkap tentang masalah yang diteliti. Jenis penelitian ini adalah pendekatan deskriptif yaitu dengan mendeskripsikan data dari variabel penelitian secara sistematis, faktual dan akurat mengenai fakta-fakta yang diperoleh dengan menelaah seluruh data yang tersedia.

Teknik pengumpulan data dalam penelitian ini adalah yang sangat penting dalam keberhasilan penelitian. Cara mengumpulkan data melalui metode wawancara, dan sebaran angket, serta dokumentasi.

Analisis data yang digunakan dalam penelitian ini adalah analisi data kualitatif deskriptif. Analisis kualitatif deskriptif digunakan untuk mendeskripsikan data dari variabel penelitian ini secara sistematis, faktual dan akurat mengenai fakta-fakta yang diperoleh dengan menelaah seluruh data yang tersedia. Data yang didapatkan melalui metode wawancara, sebaran angket, serta dokumentasi dengan temuan lainnya.

Data kualitatif deskriptif adalah data informasi berbentuk kalimat yang memberikan gambaran tentang pemahaman guru tentang layanan bimbingan dan konseling yang dapat di analisis secara kualitatif. Berikut menentukan kriteria tingkat pemahaman guru tentang layanan bimbingan dan konseling dengan kriteria sebagai berikut :

Tabel 1.1. Kriteria Tingkat Pemahaman

\begin{tabular}{ll}
\hline \multicolumn{1}{c}{ Rentangan Nilai } & \multicolumn{1}{c}{ Kriteria } \\
\hline $81-100$ & Sangat Baik \\
\hline $61-80$ & Baik \\
\hline $41-60$ & Cukup \\
\hline $21-40$ & Kurang \\
\hline $0-20$ & Kurang Sekali \\
\hline
\end{tabular}

\section{HASIL DAN PEMBAHASAN}

Berdasarkan data Direktorat Jenderal Pendidikan Anak Usia Dini dan Pendidikan Masyarakat bahwa Kabupaten Gowa dengan jumlah Lembaga PAUD tahun ajaran 2015/2016 Semester GANJIL sebanyak 238 Satuan lembaga PAUD. Untuk Wilayah Kecamatan Somba Opu, berdasarkan perijinan tahun ajaran 2015/2016 Semester GANJIL sebanyak 63 satuan lembaga. Yang ada perijinan sebanyak 14 dan tidak ada perijinan sebanyak 49. 
Pemahaman Guru Taman Kanak-Kanak Tentang Pengetahuan Layanan Bimbingan

Konseling dan Pelaksanaan di Kecamatan Somba Opu Kabupaten Gowa

Lembaga pendidikan Taman Kanak-kanak di wilayah Kecamatan Somba Opu Kabupaten Gowa yang menjadi penelitian ini membutuhkan subjek sebanyak 30 responden dari 14 Taman Kanak-kanak. Kualifikasi pendidikan Guru Taman Kanak-kanak Kecamatan Somba Opu lulusan S1 terdiri dari 19 orang guru dan D2 terdiri dari 4 orang guru, bahkan masih banyak guru Taman Kanak-kanak tersebut lulusan SMA yang terdiri dari 7 orang.

Data hasil penelitian pemahaman guru taman kanak-kanak tentang layanan bimbingan dan konseling menunjukkan bahwa diketahui banyak responden 30, jumlah skor keseluruhan 1227, dari rentang skor 30 sampai dengan 59 didapat hasil rata-rata sebesar 40,9 dan simpangan baku sebesar 5,84. Adapun data terendah dengan skor sebesar 30 dan data dengan skor tertinggi 58. Median terletak pada skor 40 dan nilai tengah modus pada skor 40. Deketahui baanyak 5 kelas, rentang 28, panjang kelas 6 .

Hasil penelitian tentang Pemahaman Guru Taman Kanak-kanak Tentang Layanan Bimbingan dan Konseling Kecamatan Somba Opu Kabupaten Gowa secara keseluruhan terdapat 10 orang guru atau sekitar 33\% dengan tingkat kemampuannya yang memperoleh rentang nilai 41-60 dengan kategori cukup, kemudian terdapat 30 orang guru atau sekitar $67 \%$ yang memperoleh rentang nilai 21-40 dengan kategori kurang.

Dari hasil penelitian menunjukkan bahwa pemahaman Guru Taman Kanak-kanak Di wilayah Kecamatan Somba Opu Kabupaten Gowa memiliki tingkat kemampuan tentang layanan bimbingan dan konseling terhadap 20 orang guru Taman Kanak-kanak dengan katrgori sangat kurang dan terdapat 10 orang Guru Taman Kanak-kanak dengan kategori cukup. Ini berarti masih banyak Guru Taman Kanak-kanak memiliki kemampuan pemahaman kurang.

Pemahaman guru tentang layanan bimbingan dan konseling pada taman kanak-kanak sangat kurang, layanan bimbingan konseling yang di lakukannya selama ini tidak berlangsung dengan baik karena sistem pengelolaan tidak jelas, tidak sistematis, dan tidak terarah, jadi dalam pelaksanaanya guru tidak memahami dan tidak memiliki pemahaman tentang layanan bimbingan dan konseling.

Keberhasilan guru dalam memahami layanan bimbingan dan konseling di sekolah juga di tentukan latar belakang kualifikasi gurunya. Latar belakang guru yang lulusa S1 terdiri dari 19 orang guru dan D2 terdiri dari 4 orang guru, bahkan masih banyak guru Taman Kanak-kanak yang lulusan SMA yaitu terdiri dari 7 orang

Syarat untuk di jadikan guru kelas sebagai guru konselor yaitu guru yang memiliki kualifikasi Strata 1. Untuk itu guru yang memiiki kualifikasi Strata 1 di jadikan sebagai guru konselor yang dapat memfasilitasi pertumbuhan dan perkembangan anak sedangkan guru yang memiiki

JECIES: Journal of Early Childhood Islamic Education Study

Vol. 02, Nomor 01, Maret 2021 
kualifikasi diploma 2 dan lulusan SMA di haruskan anjut menempuh jenjang Strata 1 untuk meningkatkan kualitas dan mutu pendidikan.

Pelaksanaan layanan bimbingan dan konseling di taman kanak-kanak di laksanakan guru dalam pembelajaran yaitu layanan konseling individual, bimbingan kelompok, dan konseling kelompok. Dimana konseling individual ini bertujuan agar anak dapat memahami lebih dalam tentang dirinya sendiri, mengeksplorasi diri sendiri, dan menerima diri sendiri dalam menyesuaikan lingkungannya.

Pada Bimbingan Kelompok pada anak di maksudkan untuk mencegah berkembangnya masalah atau kesulitan pada anak didik, di dalam bimbingan kelompok anak di kelompokkan secara campur ada yang tinggi, sedang dan kurang sehingga dapat di peroleh suasana belajar yang kondusif dimana anak yang pintar dapat memberikan pengaruh positif kepada anak yang kurang belajar.

Sedangkan pada Konseling Kelompok, anak di berikan bantuan dan kemudahan dalam pertumbuhan dan perkembangannya. Seperti bermain, yang merupakan kegiatan yang menyenangkan bagi anak-anak dan juga berguna untuk mengembangakan potensi, membantu memecahkan masalah anak. Guru Taman Kanak-kanak pada saat anak bermain selalu memperhatikan aktivitas dan mengajak anak yang kurang untuk bermain bersama.

\section{SIMPULAN}

Pemahaman guru tentang pengetahuan layanan bimbingan dan konseling di TK masih kurang. Hal ini terlihat dari 30 orang guru TK terdapat 20 orang guru yang mempunyai skor rentang nilai 20-21 dengan presentase $67 \%$ menunjukkan tingkat kemampuan kurang, kemudian 10 orang guru mempunyai skor rentang nilai 41-60 dengan presentase 33\% menujukkan tingkat kemampuan cukup. Layanan bimbingan dan konseling yang di laksanakan guru dalam pembelajaran di Taman Kanak-kanak yaitu konseing individual, bimbingan kelompok dan konseling kelompok.

\section{DAFTAR PUSTAKA}

Arikunto, Suharsimi. Prosedur Penelitian Suatu pendekatan praltik. Jakarta: Rineka Cipta, 2010.

Dewi, Rosmala. Berbagai Masalah Anak Taman Kanak-kanak. Jakarta: Dirjen Pendidikan Tinggi, 2005.

Hildayani, Rini. Penanganan anak berkelainan (Anak dengan Kebutuhan Khusus). Banten: Universitas Terbuka, 2013

Susanto, Ahmad. Bimbingan dan konseking di taman kanak-kanak. Jakarta: Prenada Media, 2015 
Pemahaman Guru Taman Kanak-Kanak Tentang Pengetahuan Layanan Bimbingan

Konseling dan Pelaksanaan di Kecamatan Somba Opu Kabupaten Gowa

Suyadi. Buku Pegangan Bimbingan dan Konseling untuk PAUD. Jogjakarta: DIVA Press. 2009

Willis, Sofyan S. Konseling Individual Teori dan Praktek. Bandung: Alfabeta, 2007

$$
\text { Program Bimbingan dan Konseling. }
$$

http://darmayulia17.blogspot.com/2012/12/program-bimbingandam-konseling-untuk.html

Jenis Layanan Bimbingan Konseling di Sekolah http://geograph88.blogspot.co.id/2015/04/apakah-kamu-pernahmasuk-ruang-bk-di.html

Daftar Lembaga PAUD Tahun Ajaran 2015/2016 Semrster GANJIL http://121.100.18.250/man-

paud/index.php?r=site/sp_daftar/1v/2/id/190304\%20\%20/a1/ptk _pnsnonpns 